\title{
The Alexandria Library and the Work of the International Friends
}

\section{Alan Hopkinson *}

\begin{abstract}
The Alexandria Library is well known, less known is the work of the International Friends. International friends' groups have been set up with support from UNESCO. The original library's origins and how it met its end are obscure. The rebuilding of the new library concluded with its being opened in 2002. An acquisitions policy is in place and materials are provided with support from Friends. looking to the future the library is hosting a mirror of the Internet Archive.
\end{abstract}

Keywords: Alexandria Library, Library friends, Acquisitions policy, Library architecture, Internet archive.

\section{International Support for the Alexandria Library}

In the early days of the idea of the Alexandria Library, UNESCO were very keen to procure interest of every kind internationally to ensure the project was not seen as merely an Egyptian project. They encouraged the setting up of Friends groups in different countries to channel support for the new Library. UNESCO have a website for them, so people can contact the appropriate group (Friends Associations, 2004). In the UK a Friends Group was set up which concentrated on raising funds for the purchase of a microfiche of 15,000 Arabic manuscripts in the collection of the British Library. We did this by producing a book called Arabic Treasures of the British Library which we sold to 'donors' and which contains a selection of material from the best or more interesting of the manuscripts which have

\footnotetext{
* Head of Library Systems, Middlesex University London - UK (a.hopkinson@mdx.ac.uk).
} 


\title{
İskenderiye Kütüphanesi ve Uluslararası "Dostlar" Gruplarının Çalışmaları
}

\section{Neslihan Burcu Akdağ (Çev.)}

\begin{abstract}
Öz
Iskenderiye Kütüphanesi iyi bilinir; daha az bilinen ise, onun uluslararası "Dostlar" gruplarıdır. Dostlar grupları, UNESCO'nun desteği ile kurulmuşlardır. Ilk kütüphanenin nasıl kurulduğu ve nasıl sona erdiği bilinmemektedir. Yeni kütüphanenin kuruluşu, 2002'deki açılışılla tamamlanmıştır. Bir sağlama politikası sürdürülmekte ve Dostlar gruplarının destekleriyle kaynak alınmaktadır. Geleceğe dönük olarak kütüphane, Internet Arşivi'nin bir aynasına da ev sahipliği yapmaktadır.
\end{abstract}

Anahtar sözcükler: Iskenderiye kütüphanesi, Kütüphane dostları, Sağlama politikası, Kütüphane mimarisi, Internet arşivi.

\section{İskenderiye Kütüphanesi için Uluslararası Destek}

İskenderiye Kütüphanesi fikrinin doğduğu ilk günlerde, UNESCO, bunun sadece bir Mısır projesi olarak görülmemesi için her türlü uluslararası ilgiyi çekebilme konusunda çok istekli olmuş ve yeni kurulacak kütüphaneye destek verilmesi amacıyla çeşitli ülkelerde "Dostlar" gruplarının kurulmasına öncülük etmiştir. UNESCO'nun bu gruplar için bir web sitesi bulunmakta ve kişiler ilgili oldukları grupla, bu site aracılığı ile temas kurabilmektedir (Friends Associations, 2004). Yapılan işlere gelince, örneğin Ingiltere'de bir Dostlar grubu, British Library'nin koleksiyonunda bulunan 15.000 Arapça elyazmasının yüklendiği mikrofişin satın alınabilmesi için para toplama üzerinde yoğunlaşmıştır. Bu nedenle, mikrofişe kaydedilen elyazmaları arasındaki en iyi ve en ilginç olanları biraraya getiren British Library'nin Arapça Hazineleri adlı bir kitap üretilmiş ve bu kitap 'bağışçı'lara satılarak para toplanmıştır. Bu mikrofişleme işi aslında Riyad'daki Kral Faysal Araştırma ve Islami Çalışmalar

\footnotetext{
*Ingilizce-Fransızca Çevirmen, Fransızca Bölüm Şefi, SESRTCIC Attar Sok. No:4 GOP Ankara
} 
been microfiched. The microfiching was incidentally done in collaboration with the King Faisal Centre for Research and Islamic Studies in Riyadh. The British Library agreed to make a reduction of the cost of the microfiche, and a generous loan from a publisher made it possible to give the microfiche collection to the Library in time for its official opening in October 2002.

Other countries have friends groups. In some countries they consist of librarians who like the idea of resurrecting the Ancient Library of Alexandria and can see it as a repository for many kinds of materials. This is the case in Norway where there is a strong interest because the architect of the Alexandria Library is the Norwegian company Snohetta. They have done a great deal to raise money for Norwegian furniture. Other groups (not predominantly librarians as you would guess) have suggested rooms of material donated by countries and kept as separate collections, surely a librarian's nightmare.

In other countries the membership is related to the Alexandrian expatriate community. Alexandria itself since its founding has been a melting pot, a place where civilisations converge. It is the meeting point of Asia, Africa and Europe, since Europe is only across the Mediterranean and since for much of its most important years it was a Greek colony. The Greeks have a special interest in it, so the Greek Friends persuaded the Greek Foreign Ministry to make a large donation to the project half for the Library and half for a statue of Alexandria the Great to be placed outside it. Unfortunately the local authority planners could find no place for it nearby so it now stands in the middle of a ceremonial boulevard about a kilometre distant. The French were also a colonial power and the street names were French before they were arabicised after Suez. Old people still use the old names but the French and Arabic usually have different meanings so are no clue to each other! The French have supported the Library as much as any other country. Like the UK Friends, the interested membership consists of a large number of the great and the good such as retired senior librarians, civil servants, authors and such like. But the late President Mitterand pledged support for the Library and the French government gave a large sum towards the purchase of a software system for library management encompassing the control of multimedia material. 
Merkezi ile kurulan bir işbirliği içerisinde yapılmıştır. British Library de mikrofiş maliyetlerinde bir indirim yapmayı kabul etmiş ve yayıncının bonkör bir katkısı ile mikrofiş koleksiyonu, Ekim 2002'deki resmi açıış̧ında Kütüphane'ye verilmiştir.

Başka ülkelerde de dostlar grupları bulunmaktadır. Bazı ülkelerde bu gruplar Eski İskenderiye Kütüphanesi'ni yeniden canlandırma fikrini benimseyen ve burasının çeşitli kaynaklar için bir depo olabileceğini hayal eden kütüphanecilerden oluşmaktadır. Aynı düşünce ile, İskenderiye Kütüphanesi'nin yapımcısı Snohetta firmasının ülkesi olan Norveç'de de, bu konuya büyük ilgi gösterilmektedir. Norveç Dostlar grubu, kütüphaneye Norveç mobilyaları sağlamak için para toplamak üzere büyük gayret göstermiştir. Diğer gruplar (ki bunlar tahmin edilebileceği üzere çoğunlukla kütüphanecilerden oluşmamaktadırlar) ülkelerin oda bağışında bulunmalarını ve kaynakların odalarda ayrı koleksiyonlar halinde korunmasını önermişlerdir ki, böyle bir yaklaşım, şüphesiz ki kütüphanecinin kabusudur.

Diğer ülkelerde üyelik, o ülkelerde bulunan İskenderiye kökenli toplulukla da ilişkilidir. Iskenderiye'nin kendisi, kurulduğundan beri medeniyetlerin buluştuğu bir yer olduğundan, zaten toplulukların kaynaşma yuvasıydı. Avrupa, Asya ve Afrika topluluklarının buluşma noktası idi ve Avrupa'ya geçiş sadece Akdeniz üzerinden sağlandığı için, Iskenderiye en önemli yıllarının çoğunda bir Eski Yunan kolonisi idi. Dolayısıyla Yunanlıların bu projeye karşı özel bir ilgisi vardır. Bu ülkedeki Dostlar grubu Yunan Dışişleri Bakanlığı'nı, yarısı kütüphane projesine ve yarısı da Kütüphane'nin dışına yerleştirilecek olan Büyük İskender heykeline tahsis edilmek üzere büyük bir bağış yapmaya ikna etmişlerdir. Maalesef yerel yönetim plancıları, bu heykel için kütüphaneye yakın bir yer bulamadıklarından, şu anda heykel, kütüphaneye giden tören bulvarının üstünde ve ondan bir kilometre uzaklıkta bulunmaktadır. Fransızlar da burada sömürgeci bir güç idiler ve buradaki cadde isimleri, Süveyş'i örnek alarak Arapçalaştırılmadan önce Fransızca idi. Yaşlı insanlar hala eski isimleri kullanmakta; ancak Arapça ve Fransızca isimlerin anlamları birbirlerini karşılamadığından, aynı yolun bir ismi, diğer dildekini anımsatmıyor tabii. Fransızlar da kütüphaneyi diğer herhangi bir ülke gibi desteklediler. Ingiliz Dostlar grubunda olduğu gibi, ilgili Dostlar grubu üyeleri, birçok büyük veya önemli emekli kütüphaneciler, memurlar, yazarlar ve benzeri 
Many of the countries which have links with Alexandria as a city run social events to raise money. Baltimore in the USA is twinned with Alexandria and they have supported the Library by collecting books from all over the USA and shipping them to the Library, the cost of the shipping having been raised by social events and donations. There is an International Friends meeting from time to time when the different national Friends Groups meets to exchange ideas. Now the Library has opened there is the possibility of a different kind of Friend. A user who did not qualify to use the Library as a local resident could join the Friends and get access to extra facilities. The Friends of the British Library has such a scheme and a room is made available for the Friends to sit and read the daily newspapers (which otherwise are not available in the British Library on their day of issue!). The Alexandria Friends are such a group. Founded over a year ago, they are supporting many aspects of the Library such as the conferences that take place in the new conference centre which to them is an integral part of the Library's mission. Of course it must be remembered that to the business community in Alexandria the influx of conference attendees is more important than the trickle of scholars who might come to consult the library materials. The nearest Friends groups to the Balkans are the Bulgarian and the Greek Friends.

\section{The Original Library}

No one really knows very much about the original Library, certainly no one knows how it met its end. An interesting account is available on the web anonymously, entitled 'The Mysterious Fate of the Great Library of Alexandria' (Hannam, 2003). It is quite likely that it just petered out during the decline of Alexandria in the 7th century AD. It was definitely founded by Ptolemy II in Alexandria which had been founded by Alexander the Great on a flying visit and this became the capital of the last dynasty of Pharaohs descended from Ptolemy, Alexander's general. The Library formed part of a museum but it is not clear whether it was a separate building or not. One story goes that Julius Caesar attacked Alexandria in pursuit of Pompey and finding himself about to be cut off by the Egyptian fleet he set fire to the enemy ships. The fire spread and engulfed 400,000 scrolls in the Library. Subsequently Alexandria remained a place of learning and there were almost certainly libraries there 
nitelikli kişilerden oluşmaktadır. Müteveffa Başkan Mitterand Kütüphane'ye yardım sözü vermiş ve Fransız Hükumeti, Kütüphane yönetimince kullanılmak üzere çoklu ortam kaynaklarının kontrolünü de sağlayabilen bir yazılım sistemi satın alınabilmesi için büyük bir bağışta bulunmuştur.

İskenderiye ile şehir olarak bağlantısı bulunan çoğu ülke, para toplayabilmek için sosyal faaliyetler düzenlemektedir. ABD'deki Baltimore Iskenderiye'nin kardeş şehridir ve buradaki Dostlar, ABD'nin dört bir yanından kitaplar toplayarak Kütüphane'ye yollamak suretiyle onu desteklemişler, kitapların yollanma masraflarını da düzenlenen toplumsal faaliyetler ve bağışlarla karşılamışlardır. Farklı ulusal Dostlar gruplarının buluşarak fikir alışverişinde bulunmalarını sağlamak üzere, zaman zaman Uluslararası Dostlar toplantısı düzenlenmektedir. Kütüphane artık açılarak faaliyete geçtiği için, daha değişik biçimde de Dost olmak mümkündür. Kütüphaneyi kullanma imkanlarına ulaşamayan yerel sakinler, artık Dostlar gruplarına katılarak sunulan ek olanaklara erişebilmektedirler. Örneğin British Library Dostları'nın böyle bir uygulaması mevcuttur. Gazeteler, çıktıkları gün British Library'de kullanıma sunulamamaktadır. Ama Dostlar'ın oturması ve günlük gazeteleri gününde okuyabilmeleri için bir oda hazırlanmıştır. Alexandria Kütüphanesi Dostları da böylesine bir gruptur. Bir yıldan fazla bir zaman önce kurulmuş olan bu grup, Kütüphane'nin birçok işlevini desteklemektedir; örneğin onlara göre Kütüphane misyonunun ayrılmaz bir parçası olan, yeni konferans merkezinde yapılmakta olan konferanslar gibi... Tabii bu bağlamda akla geldiği gibi, İskenderiye'de ticaretle uğraşan topluluk için de çok sayıdaki konferans katılımcısı, Kütüphane kaynaklarını kullanmaya gelen bir avuç bilim adamına nazaran daha önemlidir. Bu bakımdan en yakın Dostlar grupları Balkanlar'da bulunan, Bulgarlar ve Yunanlılar'dır.

\section{Eski Kütüphane}

Aslında, ilk kütüphane hakkında hiç kimse gerçekten pek fazla bilgi sahibi değildi ve kuşkusuz hiç kimse, o kütüphanenin nasıl ortadan kalktığını bilmemektedir. Internette, yazarı belli olmayan "Büyük Iskenderiye Kütüphanesi'nin gizemli kaderi” adlı ilginç bir hikaye mevcuttur (Hannam, 2003). Kütüphane, büyük bir olasılıkla MS 7. yüzyılda İskenderiye'nin çöküşü ile birlikte varoluşunun sonuna yaklaşmaya başlamıştır. Kütüphanenin 2. Ptolemaios 
but whether they ever achieved the same stature as the original Library, no one can say. If libraries were burnt at the time when the city converted from paganism to Christianity, no one can say but it is likely. Alternatively the same accusation could be made against Muslims when the city converted to that religion. The main conclusion is that the stories about the end of the Alexandria Library encapsulate a moral tale that books are likely to be burnt in war.

\section{Re-building the Library, the Original Concept}

The idea of the library, of rebuilding the Bibliotheca Alexandrina (its Latin name) was conceived in the 1980's and on 12 February 1990 in Aswan members of the International Honorary Commission including Heads of State signed the Aswan Declaration for the Revival of the Ancient Library of Alexandria.

They declared in their statement that the Library would be a witness to a decisive moment in the history of the human spirit and should provide a base for acquiring information for researchers all over the world. At that point a sum of 65 million US dollars was pledged to the Library from various countries. According to the architectural brief, the purpose was to return to bring to Alexandria the glory it held in ancient times.

In January 1987, UNESCO financed a feasibility study that confirmed the feasibility of the project. The aim of the Library should be to meet the cultural educational and research needs of the Egypt and the Mediterranean region.

On 26 June 1988, President Hosni Mubarak of Egypt laid the foundation stone on a site of about 35,200 square meters.

The same year an international competition was held, launched in September (UNESCO, 1988). By November 1988, 1324 applications had been registered from 74 countries. 524 were actually submitted from 58 countries. The jury worked from 17-25 September 1989. In the end Snohetta from Oslo, Norway were selected.

Work started immediately on a conference centre which has been open a number of years.

In October 1990, the Egyptian Ministry of Education signed an agreement with the Director General of UNESCO asserting the international 
tarafından kurulmuş olduğu kesindir. İskenderiye ise Büyük İskender tarafından, süregelen fütuhatı zamanında oradan geçerken kurulmuş ve İskender'in generali olan Ptolemaios'un soyundan gelen firavunların son hanedanının başkenti olmuştur. Kütüphane bir müzenin parçasıdır, fakat ayrıca bir binası olup olmadığı belli değildir. Bir hikayeye göre, Jül Sezar Pompeius'un peşinden gelip İskenderiye'ye saldırmış ve Mısır donanması tarafından engellenmek üzere olduğunu farkedince düşman gemilerini ateşe vermiştir. Yangın büyümüş ve alevler, kütüphanedeki 400.000 ruloyu yutmuştur. Sonradan İskenderiye yine bir öğrenim merkezi olarak kalmıştır ve orada muhtemelen başka kütüphaneler kurulmuş olsa dahi, bunların ilk kütüphanenin boyutlarına ulaşıp ulaşmadığı bilinememektedir. Bu kütüphanelerin, şehir çok tanrıcılıktan Hıristiyanlığa geçtiğinde tekrar yanıp yanmadıkları bilinmemektedir, ancak bu da büyük bir olasılıkla gerçekleşmiştir. Öte yandan, aynı olgu, şehir halkı Müslüman olduktan sonra da tekrarlanmış olabilir. Genel sonuç, Iskenderiye Kütüphanesi'nin sonu ile ilgili hikayelerin hepsinde, kütüphanenin bir savaş sırasında yanmış olabileceğine dair ibret alınacak bir anlatı bulunduğudur.

\section{Kütüphanenin Yeniden Kurulması: İlk Düşünceler}

Kütüphaneyi, (Latince ismiyle) Bibliotheca Alexandrina'yı yeniden kurma fikri, 80'li yıllarda ortaya çıkmıştır. 12 Şubat 1990 tarihinde, Assuan'da, bazı devlet başkanlarını da kapsayan Uluslararası Fahri Komisyon üyeleri tarafından "Eski İskenderiye Kütüphanesi'nin Canlandırıması için Assuan Deklarasyonu" imzalanmıştır.

Böylece oluşan bildiride, Kütüphane'nin insanlık tarihinde bir dönüm noktasına tanıklık edeceği ve dünyanın dört bir yanındaki araştırmacıların bilgi toplamalarına olanak sağlayan bir ana merkez oluşturacağı vurgulanmıştır. O tarihlerde, çeşitli ülkelerden Kütüphane'ye 65 milyon dolar verilmesi vaad edilmişti. Mimari brifing notlarına göre amaç, Iskenderiye'ye eski zamanlardaki ihtişamını geri kazandırmaktı.

Ocak 1987'de UNESCO'nun finanse ettiği bir fizibilite çalışması, projenin hayata geçirilebileceğini onaylayan bir sonuç vermiştir. Bu bakımdan Kütüphane'nin amacı, Mısır'ın ve Akdeniz Bölgesi'nin kültür, eğitim ve araştırma intiyaçlarını karşılamak olarak belirlenmiştir. 
community's commitment for the implementation of the 'Revival of the Ancient Library of Alexandria Project'.

In 1991, they started negotiating for the building with consultants, 40,000 volumes were acquired mainly by donation that same year and the Executive Secretariat was established.

In 1993 Snohetta began preliminary design and prepared the executive design and tender documents.

In 1994 the international tender was put out and Library staff were recruited and training started often assisted by placements in foreign libraries. UNESCO provided a project manager to see the Library off the ground, for a period of two years.

1995-1996 saw an extra 60,000 volumes added to the collection and construction began. In 2000, the VTLS Library Software package was selected; this was made possible by donations from the VTLS company and others.

As with all large buildings, such as the Bibliothèque de France and even more notably the British Library, it took longer to build than expected. The building was ready for occupation in October 2001 and for a month the public were let in just to look at the building. It could not be staffed as a library as there were not enough staff recruited. In April 2001, a new director was appointed replacing the earlier Project Manager who was an architect though with a very great knowledge of libraries. The new director is Prof. Ismail Serageldin, formerly Associate Director of the World Bank responsible for culture.

He has negotiated a new constitution for the Library. At the same time he organized the formal opening ceremony which was set to be on World Book Day and Shakespeare's Birthday on 23 April 2002. In the event this had to be postponed until 16 October as a result of student unrest in the area: the Library is in the heart of the Alexandria University campus as well as being on the Corniche which is a famous road, rather like Copacabana in Rio de Janeiro, with a beautiful view over the harbour to the medieval castle.

\section{Library Acquisitions, Developing Policies and Developing Roles}

Librarians are of course as interested in what is in the Library and in the Library's role as they are in the building itself. 
26 Haziran 1988'de Mısır Devlet Başkanı Hüsnü Mübarek, yaklaşık 35.200 metrekarelik bir inşaat alanının temelini atmıştır.

Aynı yıl, Eylül ayında başlatılan uluslararası bir proje yarışması düzenlenmiştir (UNESCO, 1988). 1988'in Kasım ayında 74 ülkeden 1324 başvuru yapılmış, bunlardan 524'ü 58 ülkeden gelmişti. 17 - 25 Eylül 1989 tarihleri arasında toplanan jüri, sonuçta Oslo, Norveç’ten Snohetta'nın projesini seçmiştir.

Çalışmalar derhal bir konferans merkezi yapımına yönelik olarak başlamıştır. Bu merkez, birkaç yıl önce hizmete açılmış bulunmaktadır.

Ekim 1990'da Mısır Eğitim Bakanlığı UNESCO Genel Müdürü ile bir anlaşma imzalamıştır. Bu anlaşma, uluslararası topluluğun "Eski İskenderiye Kütüphanesi'nin Canlandırılması Projesi”nin uygulamaya konulmasına ilişkin taahhüdünü belirtmektedir.

1991 yılında, danışmanlarla bina için görüşmeler başlamıştır. Aynı yıl büyük çoğunluğu bağış olmak üzere 40.000 cilt sağlanmış ve bir yönetici sekretarya kurulmuştur.

1993 yılında Snohetta ön tasarımın hazırlanmasına başlamış ve yürütüm taslağı ile teklif mektubunu hazırlamıştır.

1994 yılında uluslararası teklif mektubu yayınlanmıştır. Kütüphane personeli işe alınmış ve eğitimleri, çoğunlukla yabancı kütüphanelerde çalıştırılmak suretiyle başlatılmıştır. UNESCO, kütüphanenin işler hale gelebilmesi için, iki yıllığına bir proje yöneticisi atamıştır.

Başlangıç koleksiyonuna 1995-1996 yıllarında 60.000 cilt daha eklenmiş ve inşaat da başlamıştır. 2000 yılında VTLS Kütüphane Yazılım paketi seçilmiştir ki; bu, VTLS firması dahil olmak üzere bağışlarla gerçekleşebilmiştir.

Inş̧aat, Bibliotheque de France ve özellikle British Library gibi bütün büyük binalarda olduğu üzere beklendiğinden daha uzun sürmüştür. Bina, 2001 Ekim'de kullanıma hazır hale getirilmiş ve bir ay süreyle halkın, inşaatı gezmesine izin verilmiştir. Ancak bir kütüphane için yeterli sayıda personel işe alınamamıştır. Nisan 2001'de mimar olmasına karşın kütüphaneler hakkında çok derin bir bilgiye sahip olan eski proje müdürünün yerine, daha önce Dünya Bankası'nın kültürden sorumlu müdür yardımcısı, olan Prof. İsmail Serageldin, atanmıştır. 
It has not always been easy to determine this over the years since 1990 since the Aswan Declaration began to move the events along. There was originally a strand of thinking that said that the new Library should replicate the old. It should aim to contain all of literature of the ancient world which would have been found in the original Alexandria Library (as we saw earlier would that be in $47 \mathrm{BC}$ or in the elate 4 th century $A D$ ). This could only be achieved by microfiching this kind of literature.

The problem with this was that the contents of the Library would be too restrictive for the kind of project it was. But the idea of having not originals but microfilms started then and later evolved into electronic materials.

Another idea was to transfer the idea of being all-inclusive to the present time so the Library would hold everything available now. That was too much of a problem as the quantities would be too great whether in terms of storage or of digitising.

National Friends groups had schemes for adding to the materials. The UK Friends produced a bibliography of the material that they thought should be available in the Library in line with the Library's acquisitions policy which staff from the British Library had helped to develop. They restricted this to British publishers' output in the hope that this would be donated by them. After asking the Library to delete anything it had already acquired, they asked publishers to donate the material required by the Library.

One idea that came through all this was that the Library could provide a resource for scholars of Egypt in antiquity researching into any of the eras. This was felt to be valuable because Alexandria does not have a good Library for them and the resources available to them in Cairo are overcrowded. The climate of Alexandria is usually better too, being farther north and on the Mediterranean Sea.

It had to wait for the appointment of Dr Serageldin for the Library's acquisitions policy to be firmed up. Additionally he has clarified that the Library can be used by any member of the public with a reason to use it. UNESCO had already requested as early as 1997 that it should have a library for the blind and a children's library was proposed. Now that the acquisitions policy of the Library is firmly laid down, its overall aim is to provide both the national and international communities of scholars and researchers with 
Yeni müdür Kütüphane için yeni bir tüzük hazırlamıştır. Aynı zamanda, Dünya Kitap Günü olan ve Shakespeare'in doğum yıldönümüne rastlayan 23 Nisan 2002 tarihinde yapılması öngörülen resmi açıış törenini de düzenlemiştir. Ancak bu tören, o bölgedeki öğrenci hareketleri nedeniyle 16 Ekim tarihine ertelenmiştir, çünkü Kütüphane, İskenderiye Üniversitesi Kampüsü'nün merkezindedir. Ayrıca Kütüphane, ünlü bir yol olan Corniche'in de üzerinde olup, Rio de Janeiro'daki Copacabana gibi liman üzerinden bir Ortaçağ kalesine bakan muhteşem bir manzaraya sahiptir.

\section{Kütüphanenin İlk Edinimleri, Politika ve Rollerin Geliştirilmesi}

Elbette ki kütüphaneciler, sadece kütüphanenin hangi kaynakları içerdiği ve oynayacağı rolle değil, kütüphanenin binası ile de ilgilenmektedirler.

Ancak bu rolü 1990'a kadarki yıllarda saptamak her zaman kolay olmamıştır; işlev, Assuan Deklarasyonu'na göre işler yürümeğe başladıktan sonra belirginleşmiştir. Nitekim başlangıçtaki düşünce, yeni kütüphanenin eskisini tekrar ederek, onun yerini almasıydı. Yani yeni kütüphane (yukarıda da belirtildiği gibi MÖ 47 ile MS 4. yüzyıl arasında kurulu olan) eski İskenderiye Kütüphanesi'nin yerini alarak, antik dünyaya ait tüm literatürü kapsamayı amaçlamalıydı. Bu da ancak, bu tip literatürün mikrofişe geçirilmesiyle mümkün olabilirdi.

Burada sorun, kütüphanenin kapsayacağı içeriğin, projenin niteliğine göre fazlasıyla kısıtlayıcı kalmış olup olmayacağıydı. Yine de bu fikirdeki, orijinallere değil de mikrofişlere sahip olunması düşüncesi, daha sonra elektronik kaynaklara sahip olunması düşüncesine doğru gelişti.

Diğer bir görüş de, her şeyi içerme düşüncesinin çağımıza da yansıtılmasıyla, Kütüphane'nin şu anda ulaşılabilir her şeyi elinde bulundurmasıydı. Bu da, söz konusu miktarın gerek depolama gerekse dijitalleştirme yönünden çok fazla olmasından ötürü, çok büyük problemler yaratacaktı.

Diğer taraftan, Ulusal Dostlar Grupları'nın materyali artırabilmek için değişik yöntemleri vardı. Ingiliz Dostlar, Ingiliz Kütüphanesi personelinin yardımıyla, Kütüphane'nin sağlama politikasına uygun şekilde Kütüphane'de bulunması gerektiğini düşündükleri materyalin bir bibliyografyasını hazırladılar. Gerçi hazırladıkları listeyi İngiliz yayıncıların ürünleriyle sınırlamışlardı ama, bunun asıl nedeni, listedekilerin bu yayıncılar tarafından bağışlanacağı- 
unique collections and facilities focussing on Alexandria, Egyptian, ancient and medieval civilisations as well as on contemporary disciplines. The Library will also have valuable collections of science and technology resource material to help the socioeconomic and cultural development studies on Egypt and the region. Because it is a large building with a controlled climate it is good that it has taken care of some unique documents from the Alexandria Public Library, manuscripts and archives from the Governorate of Alexandria from the 19th century.

It is always difficult to estimate the size of a library's collections and probably it is more difficult in a library where gifts have been a large proportion of acquisitions.

Estimates vary but at opening it was reckoned to contain 500,000 volumes. The cataloguing has not kept pace with this. Work began using CDS/ISIS because it was a UNESCO project and that software is freely available from UNESCO. An in-house format was used. They had to choose an exchange format and in the end decided to use MARC 21 because VTLS is set up for that format. So the move to the new system was not easy even though there was a large file of records on CDS/ISIS.

\section{The Inauguration}

The Inauguration took place on 16 October 2002. Hundreds of librarians descended on Alexandria but because the Egyptian government was worried about security only a small number of librarians were able to be present at the Inauguration, led by the President of Egypt, Hosni Mubarak and his wife Suzanne Mubarak. The guest of honour was the President of France, Jacques Chirac. Those who could not be present in the Library were invited by the Greek community to watch it in their private park. However, many were also able to attend the dress rehearsal and so were able to hear the beautiful musical event which was a large part of the proceedings.

The inauguration was preceded by an international Friends Meeting at which the Director apologised that so few could attend and explained that the government had seen fit to reduce the numbers for reasons of security. The individual Friends groups were also thanked for their gifts; the UK microfiche for example was said by the head of the manuscripts department to have swelled considerably the amount of material he had access to in his collection. 
nı ummalarıydı. Nitekim, yeni kütüphaneden zaten elde olanları listeden çıkarmalarını istedikten sonra, geri kalanların yayıncılar tarafından bağışlanmasını rica ettiler.

Bütün bu gelişim çerçevesinde, Kütüphane'nin Antik Mısır'la ilgilenen bilim adamlarına araştırdıkları her dönem için kaynak sunabileceği fikri, sürekli olarak gündemde kaldı. Bu değerli bir görüştü; çünkü İskenderiye'de iyi bir kütüphane yoktu ve Kahire'de de aşıı miktarda kaynak vardı. Daha kuzeyde ve Akdeniz'de olduğu için İskenderiye'nin iklimi de genellikle daha iyiydi.

Kütüphane'nin sağlama politikasının belirginleşmesi, Dr. Serageldin'in göreve atanması ile gerçekleşti. Ayrıca Dr. Serageldin, geçerli nedeni olan herkesin kütüphaneyi kullanabileceğini açıklayarak netliğe kavuşturdu. Oysa ki UNESCO, daha önceden 1997'de, görme engelliler kütüphanesi ile çocuk kütüphanesi de olmasını teklif edilmişti. Fakat şimdi Kütüphane'nin sağlama politikası yerine oturtulduğu için, genel amacı da, gerek ulusal ve gerekse uluslararası bilim adamı ve araştırma toplulukları için, bir yandan İskenderiye ve Mısır Eskiçağ ve Ortaçağ medeniyetlerine ait ve öte yandan da çağdaş alanlarda odaklanan, başka yerde rastlanmayacak koleksiyonlar ve kolaylıklar sunmak biçiminde belirlenmiştir. Kütüphane ayrıca, Mısır ve bölgesi üzerinde sosyoekonomik ve kültürel gelişim çalışmalarına yardımcı olabilmek amacıyla da bilim ve teknoloji yönünden kaynak olabilecek değerli koleksiyonlar bulunduracaktır. Kütüphaneye İskenderiye Halk Kütüphanesi'nden bazı eşsiz belgelerin ve İskenderiye Valiliği'nden 19. yüzyıla ait elyazmaları ve arşivlerin, Kütüphane'nin klimalı büyük bir bina olması nedeniyle korunmak için taşınmış bulunması da yerinde olmuştur.

Bir kütüphanenin koleksiyonlarının boyutunu tahmin etmek zaten her zaman zor olmuştur. Hediyelerin, edinimlerin büyük bir kısmını oluşturduğu bir kütüphanede ise bu iş, herhalde daha güçtür.

Tahminden tahmine farklılaşmalar olsa da, Kütüphane'nin, açılışında 500.000 cilt içermiş olduğu düşünülmektedir. Kataloglama işlemleri bu büyümeye ayak uyduramamıştır. Bu bir UNESCO projesi olduğundan ve yazılım UNESCO'dan bedelsiz olarak edinilebildiğinden, çalışmalara CDS/ISIS kullanılarak başlanmıştır. Bu açıdan, önceleri kurum içerisinde geliştirilen bir format kullanılmıştır. Ancak sonra bir değişim formatı seçilmesi gerekmiş ve 


\section{The Design}

The design of the Library is strongly symbolic. It includes a circle inclined toward the sea, partly submerged in the ground. Seen from an aerial view it suggests the image of the sun. (Egyptian Hieroglyphs show the sun generally as a simple disc). The image of the ancient sun in contemporary terms is there to illuminate the world of human, library, and cultural activities, which complement the existing conference centre. The inclined roof brings in light and offers views of the sea from the interior, while giving the external impression of a continuing sea. A large portion of the Library itself is below ground. From the ground level it appears as a strong, cylindrical masonry form emerging from the earth, or a new moon that will grow to a full moon. It rises from this particular site like the rebirth of an earlier form: the ancient Library of Alexandria. The circle, about 16 meters in diameter, is not closed. Inverted triangle shapes (small pyramids) on the roof prevent direct light from entering the budding. Staff areas have balconies overlooking the Bay. There are nine levels. The building offers staff and users alike a new concept of physical library layout. Cascading levels of platforms contained within this single space, illuminated from the roof, provide a uniform ambience throughout the various sections of the Library. A technical spine serves the different platforms. Each level allows access to its own closed stacks; new platforms can be added, allowing internal expansion. An elevated pathway links the campus of the University of Alexandria to the library building; a plain solid wall, 35 meters above ground and 16 meters beneath ground level wraps around the cylinder providing protection from the wind and sand. The wall is covered with characters from alphabets and musical and other symbols including pre-historic 'writing' from around the world.

\section{The Future}

It remains to be seen what the future holds for the library. The building will take many years to fill, but it seems that it will prove useful as an extra resource for students of the university whose facilities need improvement. It will also be a repository for materials in need of conservation because of its excellent air-conditioned facilities.

One thing is certain: it has fired the imagination of librarians around the world. The Friedsn groups will continue. Also the imagination of people who 
(VTLS de ona göre ayarlanabildiği için) MARC 21'in kullanılmasına karar verilmiştir. Dolayısıyla yeni sisteme geçiş, CDS/ISIS'in kullanıldığı büyük bir kayıt dosyası olmasına rağmen, kolay olmamıştır.

\section{Kütüphanenin Açılışı}

Kütüphane'nin açılışı 16 Ekim 2002'de yapılmıştır. Bu nedenle yüzlerce kütüphaneci İskenderiye'ye akın etmiş, ancak Mısır Hükümeti güvenlik konusunda endişeler taşıdığından, yalnızca az sayıda kütüphaneci, Mısır Devlet Başkanı Hüsnü Mübarek ve eşi Suzan Mübarek tarafından yapılan açıışa katılabilmiştir. Açııışın onur konuğu Fransa Devlet Başkanı Jacques Chirac'tı. Açılış sırasında Kütüphane'de hazır bulunamayanlar, Yunanlı toplulukça töreni kendi özel parklarından izlemeye davet edilmiştir. Mamafih, birçok kişi giysili açılış provasına katılabilme imkanını bulmuş olduklarından, törenin önemli bir bölümünü kapsayan güzel müzikal seremoniyi dinleme fırsatını da zaten elde etmişlerdi.

Açılıştan önce bir uluslararası Dostlar toplantısı yapılmıştı. Burada da Müdür, açılışa bu kadar az kişinin katılabiliyor olmasından dolayı özür dilemiş ve hükümetin güvenlik gerekçesiyle katılımcı sayısını azaltmayı uygun gördüğünü belirtmiştir. Her bir Dostlar grubuna hediyelerinden dolayı özel olarak teşekkür edilmiştir. Örneğin, Elyazmaları Bölümü şefi, Ingiliz Dostlar Grubu'nca sağlanan mikrofişlerin, koleksiyondaki erişilebilir materyal miktarını oldukça artırdığını belirterek teşekkürünü sunmuştur.

\section{Kütüphanenin Tasarımı}

Kütüphanenin tasarımı oldukça semboliktir. Bina, yarısı toprağa gömülü, denize doğru eğimli bir daire şeklindedir. Havadan bakıldığında güneş imgesini akla getirmektedir (Mısır hiyerogliflerinde güneş, genellikle basit bir disk biçimindedir). Eski güneş imgesi, güncel anlamda, insanı, kütüphaneyi ve kültürel faaliyet dünyasını aydınlatmak için oradadır, ki bu da varolan konferans merkezi ile bütünleşmektedir. Eğimli tavan ışığı içeri alırken, içeriden denizin görülmesine izin verir ve aynı zamanda denizin sürekli olduğuna ilişkin dışsal bir izlenim yaratır. Kütüphanenin büyük kısmı yerin altındadır. Zemin hizasından bakıldığında topraktan yükselen güçlü ve silindirik bir taş form ya da zamanla büyüyerek dolunaya dönüşecek olan bir yeni ay gibi 
have new ideas has been fired. If you look on the web you will see many times that the word Alexandria has been hi-jacked by people who want to use it to indicate a grand library or even a grand digital collection. Others have thought that this is something the library could do so recently there has been a proposal for the library to store Powerpoint presentations in the medical field to enhance the transfer of medical information. This is being promote by academic medics in the USA in conjunction with the World Health Organisation. The proposal is that the Library could host these on its computers.

Already the library computers are host to a new archive which takes copies of web pages so that they can be retained for posterity. The Internet Archive has created the Wayback Machine. The Wayback Machine makes it possible to access more than 10 billion pages stored in the Internet Archive's web archive. The Wayback Machine was unveiled on October 24th, 2001 at U.C. Berkeley's Bancroft Library. The Internet Archive has donated its digital collections to the Bibliotheca Alexandrina to create a huge resource of information (The Internet, 1996). They have also offered 2000 hours of Egyptian and Worldnet television broadcasts and a book scanning facility to the Library.

So in a way the library may one day be able to host all knowledge but not in the way that it was perhaps originally envisaged, and only when knowledge itself can take up so little storage space. 
görünür. Bu, özel sitede eski bir formun, Eski Iskenderiye Kütüphanesi'nin yeniden doğuşu gibi görüntü verir. Yaklaşık 16 metre çaplı daire kapalı değildir. Tavandaki ters çevrilmiş üçgen şekiller (küçük piramitler) ışığın binaya doğrudan girmesini engellemektedir. Personele ayrılmış kısımların körfeze bakan balkonları vardır. Dokuz yükselti seviyesi mevcuttur. Bina, hem personele hem de kullanıcılara yeni bir fiziki kütüphane planı sunmaktadır. Tavandan aydınlanan, çağlayan biçimindeki platform seviyeleri Kütüphane'nin çeşitli bölümlerine aynı görüntü atmosferini sağlar. Teknik bir omurga, farklı seviyelere hizmet etmektedir. Her seviye, kendi kapalı raflarına eriştirir; öyle ki, Kütüphane'nin iç genişlemesi söz konusu olduğunda yeni platformlar eklemek mümkündür. Yükseltilmiş bir yol, İskenderiye Üniversitesi Kampüsü'nü kütüphane binasına bağlar; Bir silindirik yol, zeminden 35 metre yükseklikten yerin 16 metre altına kadar giden düz sağlam bir duvar tarafından sarmalanarak rüzgar ve kumdan korunmaktadır. Duvar, tarih öncesi "yazılar" dahil dünyanın dört bir yanındaki alfabelerden, müzik sembollerinden ve benzeri simgelerden oluşan harf ve işaretlerle kaplıdır.

\section{Gelecek}

Geleceğin Kütüphane'ye neler getireceğini bekleyip görmek gerekir. Kütüphaneyi doldurmak yıllar alsa da, bu haliyle bile, imkanlarının geliştirilmesi gereken İskenderiye Üniversitesi öğrencileri için fazladan bir kaynak olarak yarar sağlayacaktır. Mükemmel klima tesisatı ile kütüphane, aynı zamanda korunması gereken materyaller için de uygun bir depo olacaktır.

Kesin olan bir şey varsa o da, bu tesisin dünyanın her yerindeki kütüphanecilerin hayal güçlerini ateşlemiş bulunduğudur. Dostlar grupları işlerine devam edeceklerdir. Bunun yanı sıra, yeni fikirleri olan insanların da hayal güçleri körüklenmiştir. Internete bakıldığı taktirde, büyük bir kütüphane ve hatta bir dijital koleksiyonu ifade etmek için ne kadar çok "Iskenderiye" sözcüğünün kullanılmaya başlandığı görülecektir. Kütüphane vasıtasıyla neler yapılabileceği hususunda da öyle görüşler vardır ki, örneğin yakın zamanda, tıbbi bilgi transferini kolaylaştırmak amacıyla, Kütüphane'nin tıp alanında "Powerpoint" sunumlarını depolaması teklif edilmiştir. Bu fikre Dünya Sağlık Örgütü ile birlik halinde ABD'deki akademik tıp çevreleri destek vermektedir. Teklif, bu bilgilerin Kütüphane bilgisayarlarında tutulmasıdır. 
Kütüphane bilgisayarları, yeni başlayan bir arşivleme ile web-sayfalarının kopyalarını gelecek kuşaklar için saklamaya başlamışlardır. internet arşivi, "Wayback Machine" adlı bir arşiv tarama mekanizması yaratmıştır. Bu arşiv tarama mekanizması ile Internet Arşivi'nde depolanan 10 milyardan fazla sayfaya erişim artık mümkündür ve tanıtımı, 24 Ekim 2001 tarihinde Kaliforniya Üniversitesi Berkeley Kampüsü Bancroft Kütüphanesi'nde yapılmıştır. Isşte İnternet Arşivi'nin bu dijital koleksiyonları da, devasa bir bilgi kaynağı yaratılabilmesi amacıyla, İskenderiye Kütüphanesine bağışlanmıştır (Internet, 1996). Aynı bağış kaynağı Kütüphane'ye, bir kitap tarama aracı ile 2000 saatlik Mısır ve Worldnet televizyon yayınını vermek istemiştir.

Dolayısıyla, belki bir gün Kütüphane hakikaten tüm bilgiyi barındıracak hale gelebilir ama, bu, herhalde ilk başlarda tasavvur edildiği biçimde değil, bilginin depolanmasının çok az yer kaplayacağı bir gelecekte gerçekleşebilecektir.

\section{References / Kaynakça}

1. "Friends Associations" (2003, Mayıs 20). 1 Şubat 2004 tarihinde UNESCO Web sitesinde erişildi: http://portal.unesco.org /ci/en/ev.phpURL_ID=4616\&URL_DO=DO_TOPIC\&URL_SECTION=201.html

2. Hannam J. (2003). The mysterious fate of the Great Library of Alexandria. 1 Şubat 2004 tarihinde Bede's Library Web sitesinden erişildi: http://www.bede.org.uk/library.htm

3. The Internet Archive (1996). 1 Şubat 2004 tarihinde http://www.archive.org adresinden erişildi.

4. UNESCO. (1988) Bibliotheca Alexandrina: International Architectural Competition. Paris: UNESCO. 